'An Arabian in my room': Shakespeare and the Canon

\title{
Graham Holderness
}

\section{ABSTRACT}

The literary canon commonly thought of as ancient, accepted and agreed, and consistent between high and popular cultures. This article demonstrates the falsity of these assumptions, and argues that the canon is always provisional, contingent, iterable and overdetermined by multiple consequences of cultural struggle. Using definitions of canonicity from Harold Bloom, Frank Kermode and Pierre Bourdieu, the article shows how the canon is produced, consumed and reproduced. Picking up on Harold Bloom's use of a poem by Wallace Stevens, the article explores the impact of Arabic adaptations of Shakespeare on canon-formation and canonicity.

Let me begin with the definition of literary canon from a respected and generally reliable online source, The Literary Encyclopaedia:

Originally applied to books of the Bible deemed to be both genuine and authoritative, 'canon' was later extended to secular works.

Canonical status was afforded to a number of books from the classical to the modern period written by a number of authors such as Dante, Milton, Shakespeare, Austen and Dickens. These writers are venerated throughout literary history as writers of the classics; not only are they worthy of serious academic attention, they have also become 'celebrated names' holding some measure of universal acclaim. ${ }^{1}$

So the literary canon is ancient; universally accepted and agreed; and uniform and consistent between high and popular cultures. These statements are wrong in absolutely every particular. 
First: The canon is not immemorial. Scholars disagree about when it started: $16^{\text {th }}$ c., $17^{\text {th }}$ c., $18^{\text {th }}$ c.? There is an argument for saying $20^{\text {th }}$ century. Even as a general notion it does not predate the $18^{\text {th }}$ century. When scholars began to form the canon of English literature, they did not really think of it as a 'canon', and in any case it consisted entirely of poetry. Novelists like Jane Austen and Dickens could not conceivably have been part of it; or stage writers, except as poets. The $O E D$ records references, of a fairly passive type, as to something already generally understood, to a literary canon, but only from the early $20^{\text {th }}$ century. Canon as a critical concept or tool, the canon as something to be invoked, or attacked, or defended, is of very recent date, possibly post-1970. The first MLA meeting held to debate the canon took place in 1982. OED added the 'literary canon' to its senses of 'canon' in its 2002 update.

Second: The canon is not something universally accepted and agreed, with the one exception of Shakespeare, who has hardly ever escaped the net of any canonical construction. 'Shakespeare is the canon. He sets the standards and the limits of literature'. 'WWithout Shakespeare, no canon'. (Bloom, p. 40) The Literary Encyclopaedia also cites as core-canonical authors Dante, Milton, Austen, Dickens. Austen was pretty much ignored by the academy until the $20^{\text {th }}$ century. It was F.R. Leavis who assumed and promulgated her greatness. At the same time, of course, he excluded Dickens very decisively from The Great Tradition, and also rubbished Milton, as did his mentor and combatant T. S. Eliot. ${ }^{3}$ They disagreed absolutely over Joyce and Lawrence, each canonising one, and regarding the other as a cultural heretic.

The most interesting case is Dante. The canon is sometimes said to boil down to Dante and Shakespeare. 'The Western canon is Shakespeare and Dante'. (Bloom, p. 521) 'Dante and Shakespeare are the centre of the canon because they excel all other Western writers in cognitive acuity, linguistic energy and power of invention’ (Bloom, p. 43) But Dante meant virtually nothing to 
English culture before the late $18^{\text {th }}$ century, except to other poets who read him in Italian. The first complete English translation, Carey's, appeared in 1806; the first American, Longfellow's, at the end of the $19^{\text {th }}$ century.

Dante was locked into the canon by T S Eliot in the 1920s. My first encounter with the canon was when I did English A-level in the 1960s - Chaucer, Shakespeare, Donne, Milton, Eliot. As background for Milton we read Homer, and Virgil, and Beowulf, and Dante. I of course thought this was as it was, always had been, always would be. I wasn’t aware that Dante had been canonised as an English poet as recently as 30 years before; that Donne was also in the canon only because Eliot put him in; and that Milton's place in the canon was deeply contested.

Third: The canon is not common to both high and popular cultures, though there are overlaps. I said my first encounter with the canon was at A-level, but in fact I'd encountered another canon, a more popular one, before I went to secondary school. In 1957 my parents gave me for Christmas a set of 10 books called the 'Presentation Library'. They were published by Beaverbrook Newspapers, acquired through the Daily Express. I still have one of them left today. The ten books represented a mixture of different canons. There was what we think of as truly canonical - Swift, Dickens, Shakespeare via Charles and Mary Lamb, The Golden Treasury of English Verse. And the rest were childrens' classics: Alice in Wonderland, Hans Anderson's Fairy Tales, Charles Kingsley’s The Heroes; Treasure Island, Black Beauty, and Children of the New Forest. ${ }^{4}$

You can say well, that's a set of children's' classics, not a literary canon: but it did include Swift and Dickens and Shakespeare and the Golden Treasury. At the same time those books gave access to the imaginative realms of European folk tale and Greek myth, the imperial adventure story and the absurd. It's not an exclusively English selection of texts, but rather British, and a little bit 
European. Nor is it entirely male, with Mary Lamb and Anna Sewell. It's not all high culture, but crosses over into the popular. And I'm quite sure that this canon permanently shaped my own literary development, possibly more than any subsequent studies

The literary canon proper is all about high art, the best that has been known and thought in the world, so its relation to manifestly populist writing like that of Dickens is always problematical. The Literary Encyclopaedia makes the canon sound like something that comes into being when recognised by the academy; this academic recognition then gives writers a privileged status which enables them to become popular - 'not only are they worthy of serious academic attention, they have also become 'celebrated names' holding some measure of universal acclaim'. Winning the Man Booker Prize immediately boosts your book sales.

This is Frank Kermode's view: canonization occurs when mere 'opinion' becomes 'knowledge'. ${ }^{5}$ People may like a book, buy it and read it and enjoy it, say nice things about it in the pub or on the train. But that is mere opinion, and doesn't make a book canonical. For that you need academic approval, intellectual commentary which may well be local, and provisional, and impermanent, but which plays a role in securing the 'permanent value', the 'perpetual modernity' of the canonical work. (Kermode, p. 62) Such commentary is not necessarily valuable in itself, but it confers value on the work: it is the 'medium in which its object survives'. (Kermode, p. 67) This 'continuity of attention and interpretation', has the effect of keeping a work current, accessible, perpetually intelligible. It's apparent that Kermode credits academic opinion-leaders like himself with far too much power in this process. But he does admit that the system is not based on the controlling power of any kind of centralised authority: that it's much more dispersed, and spontaneous, and fragmented than this would imply: 
The work of preservation and defense is carried on by many voices cooperating, however unwillingly, to one end, and not by a central authority resisting its challengers. (Kermode, p. 79)

Kermode of course doesn't go into much detail about those 'many voices', or to whom they belong. One suspects that they are the voices he hears around him in the SCR, and reads in the TLS. But we need to know.

The most comprehensive attempt to identify those voices, the fullest sociology of canon-formation, is that of Pierre Bourdieu. Bourdieu starts not with a body of texts but with a 'field of cultural production', and addresses the material forces and social agencies that create knowledge and value within it. Where Kermode considers 'commentary' as the 'shadow' of the work's 'substance', secondary though indispensable to its survival, Bourdieu argues that value is conferred on the work by the 'universe of belief' in which it operates:

The producer of the value of the work of art is not the artist but the field of production as a universe of belief which produces the value of the work of art as a fetish by producing the belief in the creative power of the artist. $^{6}$

The field of cultural production is composed of objective material relations between various social agents and institutional influences, each of which plays a role in the consecration of particular works of art and in formal recognition of individual authors. ${ }^{7}$

To survey the 'field of production' for literature one would consider as 'agents': the publishing industry; the agencies that receive and review books, from learned journals to the Sunday papers; educational institutions, which both select books via curricula and syllabi, and train writers and critics ('the reproduction of producers'); literary prizes; media exposure given to writers and writing; arts councils, research councils and other funders; learned academies; 
theatre, film and media producers; the infiltration of literary reputations into civic and popular culture; etc. In short canonization is effected through what Bourdieu calls ‘a whole market of symbolic goods’.

Bourdieu converges with Kermode when he suggests that the process of canonization entails a gradual process of 'familiarization':

The consecrated authors dominating the field of production tend also to make gradual inroads into the market, becoming more and more readable and acceptable the more everyday they seem as a result of a more or less lengthy process of familiarization. ${ }^{8}$

Thus a gradual process of 'conscious or unconscious inculcation' leads people into accepting an established hierarchy of authors as 'self-evident'. But where Kermode assumes that the works possess certain aesthetic properties (though these are not fixed meanings, but a capacity for continual reinterpretation), Bourdieu sees the whole process as product of 'the field of cultural production'. The work is fetishized, by internalizing within it values that are created outside and beyond it.

As Kolbas points out, Bourdieu concurs with those who insist that 'high or official culture' is in control of canon-formation. Only certain groups with authority, 'with institutional influence on the evaluation and reproduction of selected works of literature' can exert the kind of cultural pressure necessary to construct and maintain canons. In this view the canon is held in place by structures of cultural power, and is not to be easily dislodged. But if the canon is overdetermined, the joint and cumulative product of many agents and many forces, where then does the real power lie? Who has the final say? Though he suggests that 'it would be foolish to search for an ultimate guarantor', Bourdieu ultimately attributes the highest power of canonisation to institutions of education. 
It is impossible to understand the peculiar characteristics of restricted culture without appreciating its profound dependence on the educational system, the indispensable means of its reproduction and growth. ${ }^{9}$

Education systems legitimate the canon by producing 'aware consumers' as well as 'sacralizing commentaries'. 'The infallible sign of consecration' in the field of cultural production 'is constituted by the canonization of works as classics by inscribing them in curricula'.

So the canon is a powerful cultural formation. But because the authors and works inside the canon depend for their mediation on the powers of the cultural field, they are not in themselves powerful. And because the works and authors of the canon are subject to the dispensation of cultural powers, their place within the canon can in practice be reviewed and revised when there is a shift in the configurations of cultural power. Bourdieu discusses the example of the Academie Française, which lost its authority to the literary salons of the bourgeoisie, a process that effected consequential changes in the canon. 'The literary field' is in itself according to Bourdieu lacking in institutional concentration, in central authority: it is 'weak'.

It's easy to think of examples of books and writers that worked their way into the canon via academic lobbying. I'm quite sure that D H Lawrence and James Joyce moved from coterie artists to great masters only with the assistance of F R Leavis and T S Eliot. But while this may apply to avant-garde forms of writing that are simply not accessible to a mass readership without critical exposition, in key examples the opposite is true. Writers such as Austen and Dickens and Shakespeare established their reputations through popularity, and were acknowledged by the academy only later (sometimes much later). This popular celebrity is not canonicity in the Kermode and Bourdieu senses, since it's just the cumulative net effect of ordinary readers making the decision to read a 
certain book, frequent a certain author or attend a certain playhouse - it's not about a list of authors, or how authors relate to one another, or the proper shape of a national culture. It's just 'opinion'. Of course this popular readership scene may be influenced by academic opinions, but it certainly isn’t controlled by them.

So the academy may assume leadership of canons, but the decisions of common readers clearly have something to do with their formation. And there are many canons. In 1957 I read one canon, a partially popular one. At grammar school I read another, probably the most fully canonical construction I've ever come across, the A-level syllabus. At Oxford as an undergraduate in the 1960s, there was no formal syllabus, no written curriculum, no explicitly-defined canon: you just read what was there. What was there was pretty much what you'd expect, but not really selected or rigorously hierarchized at all. The canon was implicit rather than explicit, and no-one felt the need to defend it. By the time I was a postgraduate student I'd become a card-carrying Leavisite, so would have no truck with James Joyce, or Thackeray, or Auden, or anything that wasn't in The Great Tradition or New Bearings in English Poetry. Fortunately this didn't last, and by the 1970s I was engaged in writing on working-class fiction, cultural politics, Shakespeare, nationalism and the canon, etc. (though uncomfortably, as I was working in a Leavisite English department at University College Swansea!).

The canon is something that is periodically invented, contested and reinvented. It's invented typically by powerful cultural critics - T S Eliot, F R Leavis, Northrop Frye - who are not simply invoking a self-evident corpus of texts, but rather constructing or reconstructing a corpus that has been attacked, or has fallen into disarray, or perhaps has never existed in quite that form. 'The literary canon’, said Kermode, ‘is actually defined by attacks upon it’. (Kermode, p. 23) 
'The means to destroy the canon', says Bloom, 'are very much at hand'. (Bloom, p. 4)

It is certainly self-evident that literature is a very different animal now to what it was in the 1960s. That is in terms of what there is available to read, what gets published and reviewed and promoted; what gets prescribed on school and university programmes; what gets critically defended and affirmed; what wins prizes, gets talked about in the media, gets anthologized, gets critically acclaimed and studied. All this is hugely different. But these alterations have not been produced by the fragmentation of a canon, though we might call that a symptom of the larger change. They've been produced by social developments, by educational progress, by cultural reconfigurations, by political action. The literature now studied in all British universities is diverse, and multi-cultural, and inclusive and representative: as is the literature that's widely read by a mass readership, and featured in the media, and talked about in book groups and reading circles. But that's surely got something to do with the fact that the population of schools and universities, staff and pupils is also diverse and multicultural and inclusive and representative, as is the reading public and the media audience. No-one would argue that this is some sort of automatic process that just happens by itself. Perhaps, had it not been for the demands of political movements - civil rights, anti-racist, feminist, socialist, educationally progressive - all this diverse population would still be reading just Dante and Shakespeare. If they ever did. But I seriously doubt that. Rather the production and defence of the canon is as much a product of this process as is the contemporary inclusive curriculum. Once people start to list books and authors, and to insist on their surpassing value, and to rubbish everything else by comparison, they are already strongly influenced by a different cultural profile, already engaged in a rearguard action, and already reinventing the past as a 
reaction to what's happening in the present. So the canon doesn't really exist except as a strategy of cultural politics.

Today the canon has undergone the whole trajectory from a serious critical idea to a trivialised parlour-game. If you look in a high-street bookshop like Waterstone's on the (usually very small) shelf marked 'Literature' you'll find a genre of books that purport to provide some kind of canonical apparatus. '501 Great Books of the World. 101 books to read before you die. Melvyn Bragg's 10 books that changed the world. The world's 12 greatest books'.

The person more than anyone else responsible for turning the canon into a media phenomenon is Harold Bloom. Bloom is not in my view one of the great canon-makers, but rather a great populariser, disseminator, indeed trivialiser of the canon. His best-seller The Western Canon makes it quite obvious that his quarrel with what he calls 'the school of resentment' - virtually the whole of modern criticism and theory - precedes his construction of the canon. 'The expansion of the canon has meant the destruction of the canon' (Bloom, p. 7)

At the heart of Bloom's canon is Shakespeare. Shakespeare is the best of all writers. His work displays a 'palpable aesthetic supremacy'. (Bloom, p. 20) Shakespeare measures and defines all writing that precedes him, and all writing that followed. (Bloom, p. 24) Shakespeare anticipates and contains all human knowledge, and so can't be illuminated by any new 'doctrine'. (Bloom, p. 25). This is the Western canon, but Shakespeare is universal, 'not for an age, but for all time'; not for one place but for everywhere. If you want diversity, multiculturalism, liberal pluralism, you've already got it, in Shakespeare.

If we could conceive of a universal canon, multicultural and multivalent, its one essential book would not be a scripture, whether Bible, Koran, or Eastern text, but rather Shakespeare, who is acted and read everywhere, in every language and circumstance. (Bloom, p. 38) 
Bloom expands on this in his chapter on Shakespeare in The Western Canon. Students and friends have described for me Shakespeare as they have seen him in Japanese, Russian, Spanish Indonesian, and Italian, and the general report has been that the audiences were as one in finding that Shakespeare represented them upon the stage. (Bloom, p. 49)

Shakespeare's ‘classless universalism' is based on 'surpassing literary excellence'. It 'triumphantly survives translation and transposition and compels attention in virtually every culture'. (Bloom, p. 49) Through Shakespeare Western culture is globalized, and actually provides the model for a universal common understanding:

There is a substance in Shakespeare's work that prevails and that has proved multi-cultural, so universally apprehended in all languages as to have established a pragmatic multiculturalism around the globe, one that already far surpasses our politicized fumblings towards such an ideal. Shakespeare is the centre of the embryo of a world canon, not Western or Eastern and less and less Eurocentric. (Bloom, p. 59)

On the same page as this claim for Shakespeare as global, multi-cultural, universally apprehended Bloom uses a phrase from Wallace Stevens’ poem 'Notes Towards a Supreme Fiction' to invoke Shakespeare’s prodigal generosity of imagination: 'like the "Arabian moon” in Wallace Stevens' poem, he "throws his stars around the floor"'. Bloom then quotes from the poem:

The poem, through candor, brings back a power again

That gives a candid kind to everything.

We say: At night an Arabian in my room,

With his damned hoobla-hoobla-hoobla-how, 
Inscribes a primitive astronomy

Across the unscrawled fores the future casts

And throws his stars around the floor. By day

The wood-dove used to chant his hoobla-hoo

And still the grossest iridescence of ocean

Howls hoo and rises and howls hoo and falls.

Life's nonsense pierces us with strange relation.

A throw-away quotation, to describe a throwaway genius. But the moon in the poem is not an 'Arabian moon', but a metaphorical Arabian, an Arab, a person who speaks, and speaks what appears to be nonsense, because that's what Arabic sounds like to Western ears. The moon introduces into the room of the poet's mind those associations of otherness, orientalism, magic, unreason that are all fused in the figure of the Arab. Now of course the whole point of the poem - 'Life’s nonsense pierces us with strange relation' - is that the irrational, the occult, the exotic, the strange, are aspects of the common language of nature and poetry. They belong to everything we hear, speak, write, are. The inclusion of otherness shocks ('pierces') the poet into this recognition of unrealised connection, this 'strange relation'.

With what, or whom, we might ask. A scholar of Islamic culture comments on these lines:

Stevens figures poetry itself as an unearthly source of light that illuminates most fully when the hemisphere is shrouded in the darkness of night. The errant orbit of the crescent, symbolic of Islam, provides an outlying vantage point freed from the earth's terracentric singularity. ${ }^{10}$ 
So in this reading, the poem is about Islam breaking into the closed mind of American culture.

... the appearance of Islam in American situations has been a dynamic and variable intercultural process since the earliest days of European settlement in the continents that came to be called the 'New World.' ... The violent attacks of Arabian hijackers on 9/11 revealed the hemisphere's vulnerability to an 'overseas' menace that pierced the boundaries of the Americas in ways that have been said to have ‘changed everything' (Marr, p. 522).

Perhaps Harold Bloom should have thought a bit more about this line before throwing it casually down on his page: since it directs the reader to a poem that calls into question his whole argument about the continuity of the western canon, the stability of the world canon, and Shakespeare's universality.

Let us look briefly at what Shakespeare means to those 'mysterious aliens with their strange way of speaking', the Arabs. Shakespeare entered the Arab world in the late $19^{\text {th }}$ century when the plays were translated and adapted to form the repertoire of dramatic companies in Egypt and other Arab countries.

Productions were based on translations derived from $18^{\text {th }}$ century neoclassical French versions of Shakespeare. So for instance Hamlet - in Arabic - was converted from Shakespeare's tragedy into a historical romance, in which Hamlet defeats his uncle, ascends the throne, and reigns with the Ghost's blessing: 'may you live a joyful life on earth, pardoned in heaven,11. The plays were even more radically adapted in form and style, with whole scenes deleted and songs introduced. You had Hamlet making love to Ophelia in the language of Arab love poetry. In Egypt in the late $19^{\text {th }}$ and early $20^{\text {th }}$ centuries, Hamlet flourished as a stage show rather than as a book or text, and appeared in radically revised, rewritten, and reconstructed adaptations. 
Shakespeare's absorption into Middle Eastern culture was not therefore by any means a simple process of imperialist transmission and passive colonial reception. 'Shakespeare' wrote Nadia Al-Bahar 'was transplanted into Arab soil ${ }^{12}$ Transplanted' indicates not a simple exchange but a cross-cultural migration across borders, in which the artefact becomes rooted in different soil, and there adapts itself to the local climate and conditions. Shakespeare has 'always been adapted to suit the conditions of local Arab theatres and native culture', 'assimilated', thoroughly woven into the 'fabric of Arab creative processes' (Al-Shetawi, p. 60).

Let me provide an example of this process in the work of Anglo-Kuwaiti dramatist Sulayman Al-Bassam, whose Shakespeare adaptations are now published as The Arab Shakespeare Trilogy. ${ }^{13}$ These comprise the Al-Hamlet Summit, which shifted Hamlet into the contemporary Persian Gulf; Richard III: an Arab Tragedy, which reworked Richard III for the RSC; and The Speaker's Progress, an adaptation of Twelfth Night. These works tend to be read simply as updating and re-siting of Shakespeare to secure contemporary relevance: plays about Saddam Hussein, or plays that draw parallels between $16^{\text {th }}$ century England and modern Iraq or Saudi Arabia. As such they tend to confirm for Shakespeare Bloom's kind of universality: Shakespeare's plays can be made to speak meaningfully to all times and places, 'not for an age but for all time'.

But more interestingly, Al-Bassam's work is fashioning new relations between English, historical and contemporary, and the Arabic language. Al-Bassam speaks Arabic and writes in English. All three plays of the trilogy were written in English and then subsequently translated into Arabic, mixing old and new native forms. ${ }^{14}$ Where the plays are performed in Arabic, they are accompanied with a translation, displayed in projected on-screen surtitles, in the primary language of the audience. Thus when performed at Stratford-upon-Avon, An Arab Tragedy, spoken mainly in Arabic, carried English-language surtitles; but when performed 
in Athens, the surtitles were in Greek. Al-Bassam describes part of this process in terms of a linguistic 'layering':

The texts are written in English and then produced in Arabic, undergoing a layered process of 'arabization' and re-appropriation.

But there is a further stage where the Arabic text is turned back into English, producing yet another English variation on the original Shakespeare text. Spectators of Richard III: An Arab Tragedy at Stratford encountered the unusual experience of visiting the RSC to see and hear a multi-layered performance, which invoked the familiar Shakespeare history play, but conveyed the dialogue in Arabic, which was in turn translated on video screens into a mixture of Shakespearean, modern and poetic English.

Al-Bassam's dramatic works establish new relations between English, Arabic and other world languages. The English versions have been played in the Middle East, the Arabic in the West, and both to mixed audiences of Arabic and English speakers. The performance of these works in 'arabized' English, and the 'bilingual' use of English and Arabic together in a single performance is not simply 'translation' for the convenience of different audiences. Part of the meaning of the work lies in the relational interaction of different languages, in particular between Anglo-American English and Arabic: two languages that tend to inscribe and articulate a grammar of global conflict, a clash of civilisations, but are here put together with the aim of reciprocal recognition and mutual understanding.

The complexity of this genre of writing can be grasped if we pose the deceptively simple question of authorship. In what sense is Sulayman Al-Bassam the 'author', or to use Pierre Bourdieu's term the 'originating consciousness, ${ }^{15}$ of The AlHamlet Summit or Richard III: an Arab Tragedy? Works such as this display a complex and hybrid genealogy in which we see marks of their affinity with 
Shakespeare, in both English and Arabic translations; with Al-Bassam himself, who performs a number of functions - writer, translator, adapter, director, impresario, even actor (he played a role in An Arab Tragedy at Stratford, and in The Speaker's Progress in New York and Boston); with generic contexts such as European political theatre, whose influence entered Arab culture from Eastern rather than Western Europe; and from contemporary Arabic writing, especially poetry. As we see, even the writer, who will seem the most fixed point in this matrix, presents a shifting and volatile subjectivity: bilingual; both originating writer and adapting dramaturg; both theatrical entrepreneur and performer; both inside and outside the productions. It is no more possible to predicate a linear relationship between writer and work than it is with Shakespeare himself (who was also of course both dramatist and poet, both an inveterate adapter and an original writer, both a theatrical entrepreneur and an actor in his own plays). To explain this complex set of functions we need a concept like Bourdieu's 'trajectory', 'the series of positions successively occupied by the same writer in the successive states of the literary field'. (Bourdieu, p. 189)

These works are 'hybrid' in a number of senses. They display a bilingual coupling of divided cultures. They secure a rapprochement between a familiar antiquity, and an estranged vision of the contemporary world. As stage works they show themselves capable of securing intelligibility for audiences of differing language, culture and literary knowledge. The Al-Hamlet Summit has worked successfully on stage in the Arab world but also in Britain, Europe, America and the Far East. It is therefore a global commodity that can transcend national, ethnic, cultural and linguistic barriers. But it is at the same time a form of cultural production that carries a sharp critique of the terms on which globalisation is usually proffered.

The writing of The Al-Hamlet Summit began with the experience of globalisation: 
I was in Cairo with an exiled Iraqi theatre director and a Palestinian theatre troupe from Ramallah drinking coffee in the bazaar when a boy came running past us, chanting: 'Al-Kull murtabit / Am-reeca qarabit' ('Everything is linked/America just got closer ...'). It was September the 11th and news from New York was just beginning to stream across the television screens. In all the confusion of that night, I remember the words of one of the Palestinian actors: 'The hell in New York today will bring hell to Ramallah tomorrow'. ${ }^{16}$

9/11 is the supreme instance of globalisation. The boy's chant celebrates the shrinking globe and the ease with which Islamic terrorism can reach to the very heart of America's political and economic institutions. The Palestinian actor thinks ruefully of the consequences, immediate reprisal not from America but from Israel, and against the Palestinians. Global events know no barriers of time and space.

In an article on 9/11 Tony Blair echoed these sentiments exactly. 9/11 'brought home the true meaning of globalisation'.

In this globalised world, once chaos and strife have got a grip on a region or a country, trouble is soon exported ... It was, after all, a dismal camp in the foothills of Afghanistan that gave birth to the murderous assault on the sparkling heart of New York's financial centre. ${ }^{17}$

This is the negative side of globalisation. But globalisation also provides the potential solution to such problems. Blair reflects that the West can 'use the power of community to bring the benefits of globalisation to all' (Blair, p. 119) in the form of truly universal values:

... values of liberty, the rule of law, human rights and a pluralist society ...

Values that are universal and worthy of respect in every culture. (Blair, p. 121) 
Including presumably the works of the Western Canon, which Bloom claims are 'universal and worthy of respect in every culture'.

Globalisation is not only inevitable but desirable, since it is the only route to mutual understanding and a stable world. The problem is how to develop those links without conflict and violence; without the supremacy of the West; without the suppression of alternative cultures and consequent global homogenisation. In this process, according to Al-Bassam, theatre has a critical role to play. This is quite a different approach from Tony Blair's vision of globalisation as a universalisation of enlightenment values. The 'hybridity' of Al-Bassam's work, its investment in 'cultural symbiosis' is clearly designed to form a ground of constructive dialogue between East and West.

Perhaps there are advantages of canonicity. If Shakespeare were not a virtually universal author, his work would not be available for this kind of reconstruction. But can you have the benefits of canonicity without the baggage? If Shakespeare is, by virtue of his canonical status, inextricably involved with the English language, with English culture, and with English nationality, then any foreign appropriation is still handling an exported commodity, one that retains its imperial brand. A writer like Al-Bassam runs the risk of gaining acceptance from universalists, and incurring the anger of those who see Shakespeare as an ambassador of western colonialism.

This Shakespeare is a familiar figure in modern criticism: an imperial Shakespeare whose works testify to the superiority of the civilised races, and could be used to establish and maintain colonial authority. The effigy of this linguistic imperialism was the head, the mind, of Shakespeare as a microcosm of 'the great Globe it selfe'. The linguistic achievements of that microcosmic globeshaped brain have imprinted themselves on the global map, facilitating the universalisation of English around the world. This was only possible, however, 
because the Shakespearean mind was capable of conceiving and mapping such a global image. The world can know itself in Shakespeare because Shakespeare knew the world.

Yet if the Shakespeare dispersed by linguistic imperialism around the globe is also a Shakespeare wholly or partially 'hybridised' by contact with other languages and cultures, then is it still the same old imperial Shakespeare? Or is it possible that Shakespeare 'goes native' every time he crosses a geographic or national border? A Shakespeare 'transplanted to a different soil'? A Shakespeare thoroughly assimilated to another culture's 'creative processes'?

To summarise: the canon in the professional academic sense is modern, not old; it is inconsistent, varying hugely between times and places; and it is different in different sections of the national culture. Canon-formation is defensive, reactive, custodial; and at the same time it is a radical reconfiguration of the past. As one of the contributors to Jan Gorak's Canon vs. Culture puts it, canonmakers usually meet with 'ferocious opposition' for perpetrating an 'outrageous departure from the norm, ${ }^{18}$ (Cain, 'Opening', in Gorak, Canon and Culture, 11). But they then fool everyone into believing that this is what it's always been like. 'The Canon ... is identical with the literary art of Memory' (Bloom, p. 17) But his memory seems faulty, and quite unlike anyone else's. As Kermode says, canon-formation is 'reappraisal of a past' (Kermode, p. 71) To speak of this canon that has only recently been invented, and never really got itself universally accepted, as a thing of the past, an antiquity, is misleading. When Terry Eagleton suggested we should give it to the National Trust to look after, he was colluding in the myths of origin that canonizers so expertly invent and disseminate.

And just as the canon is a reinvention, so the legendary Shakespearean universality breaks down into innumerable separate initiatives in cultural construction. Shakespeare exported easily finds a local habitation and a name 
because of its adaptability, because it is intrinsically nomadic rather than fixedly nationalistic. 'Global' Shakespeare is constructed from myriads of local Shakespeares that have mutated and taken root in other cultures, 'assimilated', 'transplanted', producing new species in the altered circumstances of a new climate and soil. Shakespeare does form a common ground between cultures, but only because those cultures can make of his work something that belongs to them.

${ }^{1}$ Available at [http://www.litencyc.com/php/stopics.php?rec=true\&UID=158] [Accessed 26 August 2014].

${ }^{2}$ Harold Bloom, The Western Canon: the Books and School of the Ages (New York:

Riverhead Books, 1994), p. 47.

${ }^{3}$ F.R. Leavis, The Great Tradition (London: Faber and Faber, 1948).

${ }^{4}$ See my Tales from Shakespeare: Creative Collisions (Cambridge: Cambridge University Press, 2014), pp. 222-225.

${ }^{5}$ Frank Kermode, Forms of Attention (Chicago: University of Chicago Press, 1985), p. 67.

${ }^{6}$ Pierre Bourdieu, Sociology in Question (London: Sage, 1993), p. 141.

${ }^{7}$ See E. Dean Kolbas, Critical Theory and the Literary Canon (Oxford and Boulder, Colorado: Westview Press, 2001), pp. 61-2.

${ }^{8}$ Pierre Bourdieu, The Rules of Art: Genesis and Structure of the Literary Field (Stanford: Stanford University Press, 1996), pp.159-60.

${ }^{9}$ Pierre Bourdieu, The Field of Cultural Production, Essays on Art and Literature (Oxford: Polity Press, Blackwell Publishers, 1993), p. 123.

10 Timothy Marr, '”Out of this world”: Islamic Irruptions in the Literary Americas', American Literary History, 18:3 (2006), p. 521.

${ }^{11}$ Translation by Tanius 'Abdoh, quoted by Mahmoud Al-Shetawi, 'Hamlet in Arabic', Journal of Intercultural Studies, 20:1 (1999), p. 44.

${ }^{12}$ Nadia Al-Bahar, 'Shakespeare in Early Arabic Adaptations', Shakespeare Translation, 3 (1976), p. 13.

${ }^{13}$ Sulayman Al-Bassam, The Arab Shakespeare Trilogy, with 'Introduction’ by Graham Holderness (London: Bloomsbury, 2014).

${ }^{14}$ See Sulayman Al-Bassam, 'Author's Preface' to The Arab Shakespeare Trilogy, p. xx.

${ }^{15}$ Pierre Bourdieu, The Field of Cultural Production: essays on art and literature, edited by Randal Johnson (Cambridge: Polity Press, 1993), p. 193.

16 Sulayman Al-Bassam, 'Introduction to the Publication of The Al-Hamlet Summit', Theatre Forum Magazine, 22(2003), p. 85.

17 Tony Blair, 'The Power of World Community', in Mark Leonard, ed., Re-ordering the World (London: Foreign Policy Centre, 2002), p. 119.

${ }^{18}$ William E. Cain, 'Opening the American Mind: reflections on the "canon” controversy', in Jan Gorak, ed., Canon vs. Culture (New York: Garland Publishing, 2001), p. 11. 